\title{
PROFITABILITY GAP IN THE MILK PRODUCTION CHAIN: EVIDENCE FROM SERBIA
}

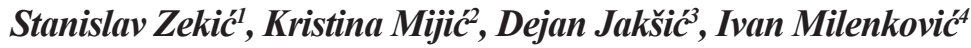

\begin{abstract}
Summary
The main goal of this paper is to compare profitability of large dairies (processors) versus large milk producers, i.e. farms with 100 or more cows, organized as companies. Profitability is measured by following indicators: return on assets and return on equity. Profitability gap analyzis shows that milk processors achieved significantly higher profitability compared to cow breeders. Furthermore research results suggest that the existence of differences in the level of profitability among the participants in the milk production primarily affects capital turnover, and then the profit margin.
\end{abstract}

Key words: profitability, milk production, dairies, ROA, ROE.

JEL: $M 21, Q 12, Q 19$.

\section{Introduction}

Agriculture production is a relatively important industry in Serbia. This is the consequence of favorable agro-ecology conditions. On the other hand, this is also the consequence of an underdeveloped economic system. Since the crop production dominates in Serbian agriculture production, its structure in Serbia is not favorable due to the fact that the generator of intensity of agriculture production - livestock breeding - participates in 1/3 of overall production. Cattle breeding dominates among livestock breeding $(>50 \%)$, while milk production is the second most important product of livestock breeding - around 30\% of the total value of animal production. Otherwise, milk production had been $8 \%$ of total Serbian agriculture output in the period 2010-2012 (Bogdanov, Rodic, 2014). Milk production in Serbia is taking place on around 156,000 farms, with more than 450,000 milking cows. Around 2/3 of Serbian

1 Stanislav Zekić Ph.D., Associate Professor, University of Novi Sad, Faculty of Economics Subotica Segedinski put no. 9-11, 24000 Subotica, Republic of Serbia, E-mail: zekics@ef.uns.ac.rs

2 Kristina Mijić Ph.D., Teaching Assistant, University of Novi Sad, Faculty of Economics Subotica Segedinski put no. 9-11, 24000 Subotica, Republic of Serbia, E-mail: mijick@ef.uns.ac.rs

3 Dejan Jakšić Ph.D., Full Professor, University of Novi Sad, Faculty of Economics Subotica Segedinski put no. 9-11, 24000 Subotica, Republic of Serbia, E-mail: jaksicd@ef.uns.ac.rs

4 Ivan Milenković Ph.D., Associate Professor, University of Novi Sad, Faculty of Economics Subotica Segedinski put no. 9-11, 24000 Subotica, Republic of Serbia, E-mail: imilenkovic@ef.uns.ac.rs

EP 2016 (63) 2 (485-499) 
farms have up to two milking cows, which represents the small semi-subsistence agriculture sector (Statistical Office of the Republic of Serbia, 2014). Such farms are not commercially intended, but are elements of social security networks in rural areas.

During the last decade dairy production in Serbia has been in constant decline. This decrease originates in Central Serbia, while there is an increase in Vojvodina (Statistical Office of the Republic of Serbia, 2014). Reduction in production in Central Serbia, that participates around $3 / 4$ of overall milk production, is caused by diminishing of production on small semisubsistence farms that are closing down due to economic unsustainability. Vojvodina, that gives around $25 \%$ of milk production with $17 \%$ of total Serbian milking cows, is a region with more intensive livestock production that are commercially intended toward milking cow farms. Therefore around $40 \%$ of delivered milk is produced in Vojvodina (Popovic, 2008).

The average milk yield of cows in Serbia has grown in the last several years, which partially amortized decrease of the total number of milking cows. Increase in milk yield of cows is more noticeable in Vojvodina, where milk yield per cow is higher than in central Serbia - a bit less than 4,000 liters per year per dairy cow, in comparison to around 2,500 liters respectively (Statistical Office of the Republic of Serbia, 2014). It is obvious that the variation in milk yield of dairy cows between regions is defined by the size of the farm (Bogdanov, Rodic, 2014). However, in comparison with EU countries, milk production per dairy cow in Serbia is very low at only $50 \%$ of the average EU-27. The situation is somewhat more favorable in comparison to neighboring countries, as the average milk yield in Serbia is higher than in Albania, Montenegro, Bosnia and Herzegovina and Macedonia, but still lower than in Bulgaria, Romania and Croatia (Volk et al., 2014).

Contrary to the milk production industry, the milk processing industry in Serbia is mainly concentrated in bigger capacities. These capacities have been recently privatized and modernized and dominate the domestic market with more than $90 \%$ of overall processing capacities in Serbia. Production of these processing capacities is mostly oriented toward liquid dairy products, while cheese production is mainly of less priority. On the other hand, there are a large number of small milk processing production facilities that cover 4-6\% of overall capacities (there are over two hundred registered dairies in Serbia, but not all of them are active - most of them are dairies of medium and small capacity). Such dairy facilities mainly operate locally, and they are especially interested in production of cheese, spreads and other fermented milk products. In Serbia although purchase is growing, number of producers who deliver milk reduces. Therefore, it implies a trend of strengthening market-oriented farmers in Serbia (Government of the Republic of Serbia, 2010).

Due to the dominance of the big processing capacities on Serbian milk market purchase, or existence of oligopsony or even monopsony structure, a relatively unfavorable position of small farmers as milk producers can be assumed. Small farms can affect the purchase price, and have problems reaching adequate milk quality, which can also negatively influence purchase price, and consequently on the profitability of production. The average price of row milk in Serbia in the period 2010-2012 was lower in comparison to all other EU countries (20\% below the EU-27 average), as well as lower than in countries in the region (Volk et al., 2014). 
The biggest share of the total amount of subsidies for agricultural producers in Serbia is for crop production. Milk production accounts for about $14 \%$ of this direct support in agriculture (Volk et al., 2014). For many years, premiums for milk has been paid to farmers in Serbia, and as of the mid-2012 it amounts to 7 dinars $(120 \mathrm{RSD}=1 \mathrm{EUR})$ per liter of milk. Necessary condition is to deliver minimum 3,000 liters per quarter. Due to this kind of production bonus payment, a large number of small farms is excluded from the system of supporting milk production, which contributes greatly to the economic unsustainability of production on small farms. A separate issue is the extent to which premium payments contribute to purchase price decrease, when it is known that the effect of subsidies paid to producers depend on elasticity coefficients of supply and demand. However, the question is whether state policy, through premium for milk production, can improve this situation.

From the standpoint of achieving profitability, larger manufacturers (i.e. farms with 100 or more dairy cows) should find themselves in a more favorable situation. These farms have modern technology, high-quality breed composition, qualified labor force and often their own crop production, which all together enables higher milk yield and milk quality and lower production costs per unit of product (Negring et al., 2009). Partially unfavorable aspect is that the selling of large quantities of milk is related to large processing capacities, i.e. large farms would be difficult to have an alternative to cooperation with small and medium-sized dairies, as is the case with small producers. On the other hand, the large dairies have an interest in large producers, since they represent the most significant raw material base of quality product. In addition, transportation issue - delivery of raw milk from large farms - is most rational in terms of organization, as well as cost-effective.

It is expected that all aforementioned aspects affect the financial results of the participants in the milk production chain. There is an ambivalent relationship between milk producers and dairies. On the one hand they are directed to each other, and the necessity of cooperation is obvious. On the other hand, there is a "fight" about the price and other conditions of sale. The result is mainly defined by the market position and financial strength of negotiators. Sustainable development in the milk production industry requires a balanced business performance, which means that the domination of one group could endanger the position of the other participants. In the long-term it could have a negative impact on both the financially stronger and weaker participants.

To explore whether the profitability of Serbian dairies differs in profitability Serbian milk producers aim to identify the economic position of some participants in the chain of milk production. Previous research of profitability of Serbian milk points out that the dairy industry is in slightly better condition than the overall Serbian market (Muminovic et al., 2012). Thus, in comparison with the dairy industry in Slovenia and Croatia, the profitability of the Serbian dairy industry is at a higher level as a result of high prices of the final products, lower production costs, and the lack of EU legislation regarding competition and the free market (Muminovic, Pavlovic, 2012). In addition, the comparative analysis of the profitability of the participants in the chain of milk production in other countries suggests the existence of disproportion in the levels of profitability between dairies and milk producers (Qian et al., 2013). Furthermore, identification of the causes of differences in the level of profitability is the 
subject of numerous researchers (see more: Kergler 2012; Wilson 2011; Soboh et al., 2011).

This paper is organized as follows. After the introduction, materials and applied methods of profitability analysis of the participants in the chain of sales of milk in Serbia are presented. On the basis of the reference analytical indicators, a comparison of profitability is made, which is then analyzed in order to identify factors that determine the levels of profitability.

\section{Materials and methods}

The profitability of a company can be analyzed using various financial indicators. The most representative indicators of profitability are the return on assets (ROA - Return on Assets) and return on equity (ROE - Return on Equity) (Wals, 2003). ROA measures a company's ability in using assets to earn net income. ROE measures how much profit (Net Income) a company generates with the shareholders equity. The following table gives an overview of key profitability indicators and reference values.

Table 1. Profitability indicators and reference values

\begin{tabular}{|c|c|c|c|}
\hline Profitability Ratio & $\begin{array}{c}\text { The method of } \\
\text { calculating }\end{array}$ & Unit & Reference value \\
\hline Return on Assets (ROA) & NI/TA & Ratio & $\geq 0.1$ \\
\hline Return on Equity (ROE) & NI/SE & Ratio & $\geq 0.15$ \\
\hline
\end{tabular}

Source: Author's illustration (according to Horngren et al., 2012; Wals, 2003)

where:

NI - net income

TA - total assets

SE - shareholders equity

For the purpose of participants' profitability comparative analysis in the chain of milk production, the companies were divided into two groups: the first group consists of companies engaged in milk production, and the second group consists of dairies. The study is based on a sample of 20 companies, which were divided into two independent samples of the 10 leading companies in the field of milk producers, and 10 leading dairies in the Republic of Serbia.

Profitability analysis was conducted for the period 2010-2013. For the purpose of research data from the financial statements of numerous companies were used, taken from the website of the Agency for Business Registers of Republic of Serbia (http:/www.apr.gov.rs). Data was processed using the statistical program SPSS IBM Statistics Version 20 (according to Berenson et al., 2012; Field 2009).

The following table shows the descriptive statistics for the profitability indicators ROA and $\mathrm{ROE}$ at the level of groups of companies from the milk producers, and a group of dairies companies. 
Table 2. Descriptive statistics for ROA and ROE on the level of groups of companies: milk producers and dairies.

\begin{tabular}{|l|l|l|l|l|l|l|l|l|l|l|}
\hline \multirow{2}{*}{} & \multicolumn{7}{|c|}{ ROA } & \multicolumn{5}{c|}{ ROE } \\
\cline { 2 - 9 } & $\mathbf{2 0 1 0}$ & $\mathbf{2 0 1 1}$ & $\mathbf{2 0 1 2}$ & $\mathbf{2 0 1 3}$ & $\mathbf{2 0 1 0}$ & $\mathbf{2 0 1 1}$ & $\mathbf{2 0 1 2}$ & $\mathbf{2 0 1 3}$ \\
\hline Milk Producers & -0.106 & -0.012 & -0.013 & 0.013 & -0.232 & -0.040 & -0.046 & 0.047 \\
\hline Mean & -0.146 & -0.130 & -0.557 & -0.185 & -1.042 & -0.797 & -1.789 & -0.419 \\
\hline Minimum & 0.177 & 0.192 & 0.176 & 0.107 & 0.387 & 0.378 & 0.454 & 0.387 \\
\hline Maximum & 0.098 & 0.087 & 0.199 & 0.081 & 0.417 & 0.334 & 0.642 & 0.213 \\
\hline Std. Dev. & 0.010 & 0.008 & 0.004 & 0.007 & 0.174 & 0.112 & 0.413 & 0.045 \\
\hline Variance & & & & & & & \\
\hline Dairies & 0.055 & 0.082 & 0.080 & 0.098 & 0.150 & 0.238 & 0.302 & 0.416 \\
\hline Mean & 0.007 & -0.116 & -0.032 & 0.002 & 0.013 & -0.564 & -0.118 & 0.021 \\
\hline Minimum & 0.386 & 0.217 & 0.205 & 0.346 & 0.773 & 0.926 & 1.709 & 0.649 \\
\hline Maximum & 0.114 & 0.091 & 0.066 & 0.101 & 0.223 & 0.389 & 0.511 & 0.225 \\
\hline Std. Dev. & 0.013 & 0.008 & 0.004 & 0.010 & 0.050 & 0.152 & 0.261 & 0.051 \\
\hline Variance & & & & & & & \\
\hline
\end{tabular}

Source: Author's calculations (based on data from the Agency for Business Registers of Republic of Serbia)

Comparing distribution of enterprises regarding profitability (whether they generate net profit or net loss) it can be seen that a greater number of milk-processing-companies managed to operate positively in the period 2010-2013. In 2010 and in 2013, all 10 companies in the sample of dairies had net profit, while the number of companies in the field of raw milk production was 6 and 5 respectively (See Table 3 ).

Table 3. Serbian milk producers and dairy processors samples 2010-2013

\begin{tabular}{|l|c|c|c|c|c|c|c|c|}
\hline \multirow{2}{*}{$\begin{array}{c}\text { Group of } \\
\text { companies }\end{array}$} & \multicolumn{2}{|c|}{2010} & \multicolumn{2}{c|}{2011} & \multicolumn{2}{c|}{2012} & \multicolumn{2}{c|}{2013} \\
\cline { 2 - 9 } & $\begin{array}{c}\text { Net } \\
\text { profit }\end{array}$ & $\begin{array}{c}\text { Net } \\
\text { loss }\end{array}$ & $\begin{array}{c}\text { Net } \\
\text { profit }\end{array}$ & Net loss & $\begin{array}{c}\text { Net } \\
\text { profit }\end{array}$ & $\begin{array}{c}\text { Net } \\
\text { loss }\end{array}$ & $\begin{array}{c}\text { Net } \\
\text { profit }\end{array}$ & $\begin{array}{c}\text { Net } \\
\text { loss }\end{array}$ \\
\hline Milk Producers & 6 & 4 & 4 & 6 & 5 & 5 & 5 & 5 \\
\hline Dairies & 10 & 0 & 8 & 2 & 9 & 1 & 10 & 0 \\
\hline
\end{tabular}

Source: Author's calculations

In order to carry out a comparative analysis of the profitability of the participants in the chain of milk production, two research goals are set: 
1) To examine whether there is a significant difference in the level of profitability between companies from the milk production sector and dairy industry.

2) If there are significant differences in the level of profitability among the participants in the chain of production of milk, to identify the causes of these differences.

Accordingly to the first purpose of research, and bearing in mind that the profitability of the most commonly measured by two analytical indicators (ROA and ROE), the following hypotheses are set:

$H_{1}$ : There is no statistically significant difference in the level of ROA between companies from milk producing industry and companies from dairy processing industry.

$\mathrm{H}_{2}$ : There is no statistically significant difference in the level of ROE between companies from milk producing industry and companies from dairy processing industry.

Differences in the level of profitability of the participants in the chain of production of milk was examined using the statistical method of mixed-design repeated measures ANOVA (see for more details: Field, 2009). For companies such as milk producers and dairies, profitability is measured on the basis of indicators ROA and ROE for the period of four consecutive years. The results of a mentioned statistical test indicates whether there is a statistically significant difference in the level of profitability between the two groups of participants: milk producers and dairies (between-subject effects) in the period 2010-2013. In addition, the results of the test indicate the changes of a level of profitability in the period 2010-2013 in the industrial sector of milk (within-subject effects).

\section{Results}

\section{ROA Analysis Results}

The results of ROA measurement indicate that companies from the group of dairies have a higher level of average profitability of the companies from the group of milk producers (see Figure 1). 
Figure 1. ROA of dairy farming and dairy processing for the period 2010-2013

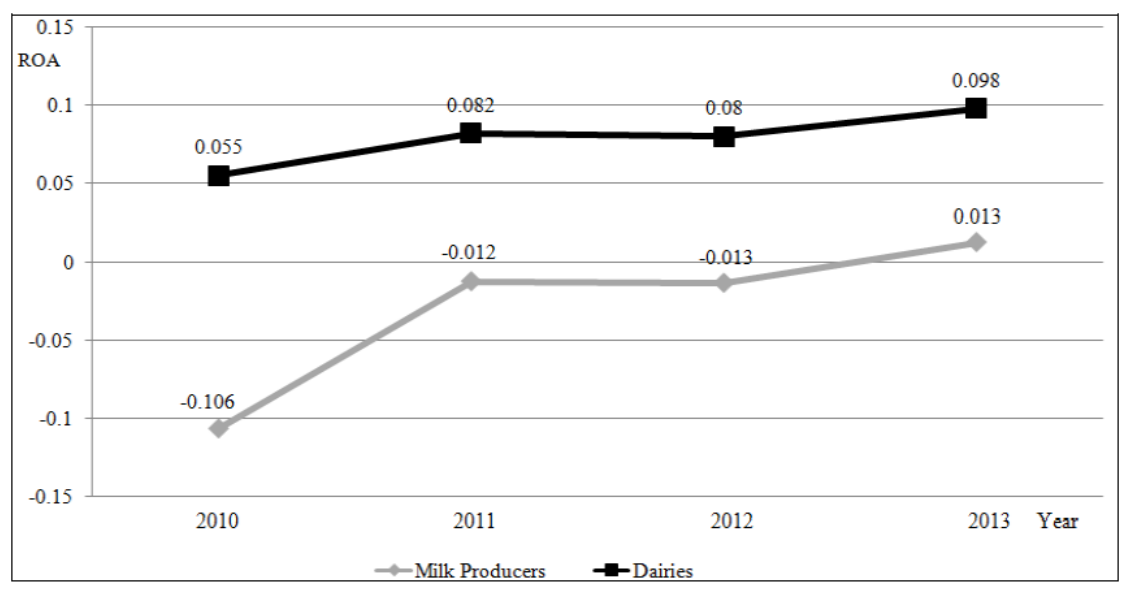

Source: Author's illustration

In accordance with a defined program of research, the significant differences in the level of ROA is tested using statistical method mixed design repeated measures ANOVA. Results of a comparison of ROA between the two groups of participants in the chain of production of milk are shown in Table 4, while the results of changes in the level of ROA over the observed period are shown in the table after it.

Table 4. Statistical significance of differences in the level of ROA between milk producers and dairies - Test of Between-Subject Effects for ROA

\begin{tabular}{|l|c|c|c|c|c|}
\hline \multicolumn{1}{|c|}{ Source } & Type III Sum of Squares & df & $\begin{array}{c}\text { Mean } \\
\text { Square }\end{array}$ & F & Sig. \\
\hline Intercept & 0.037 & 1 & 0.037 & 2.238 & 0.152 \\
\hline Dairy Industry & 0.180 & 1 & 0.180 & $\underline{\mathbf{1 0 . 9 0 3}}$ & $\underline{\mathbf{0 . 0 0 4}}$ \\
\hline Error & 0.297 & 18 & 0.016 & & \\
\hline
\end{tabular}

Source: Author's calculations, SPSS output

Since the obtained statistical value of $F(1,18)=10.903, p<0.05$ hypothesis $H_{1}$ is rejected, and the alternative hypothesis is accepted. Thus, there are significant differences in the level of ROA between dairies and milk producers, so that dairies have significantly higher levels of ROA of the company from a group raw milk production. 
Table 5. Results of changes in the level of ROA - Test of Within-Subject Effects for ROA Mauchly’s test

\begin{tabular}{|c|c|c|c|c|c|c|c|}
\hline $\begin{array}{c}\text { Within } \\
\text { Subjects } \\
\text { Effect }\end{array}$ & $\begin{array}{c}\text { Mauchly's } \\
\text { W }\end{array}$ & $\begin{array}{c}\text { Approx. } \\
\text { Chi- } \\
\text { Square }\end{array}$ & df & Sig. & $\begin{array}{c}\text { Greenhouse- } \\
\text { Geisser }\end{array}$ & $\begin{array}{c}\text { Huynh- } \\
\text { Feldt }\end{array}$ & $\begin{array}{c}\text { Lower- } \\
\text { bound }\end{array}$ \\
\hline ROA & 0.782 & $\underline{\mathbf{4 . 1 2 3}}$ & 5 & $\underline{\mathbf{0 . 5 3 3}}$ & 0.881 & 1.000 & 0.333 \\
\hline
\end{tabular}

Source: Author's calculations, SPSS output

Sphericity assumption was tested using Mauchly's test. The result of an aforementioned test $2(5)=4.123, p>0.05$ indicates that changes in the level of profitability of the participants in the chain of production of milk during the period 2010-2013 are not statistically significant.

\section{ROE Analysis Results}

Results of ROE measurement indicate that companies from the group dairy industry have better average profitability compared to raw milk producers. During the period of 2010-2013 it is noticeably increasing the level of ROE in both groups of companies.

Figure 2. ROE of dairy farming and dairy processing for the period 2010-2013

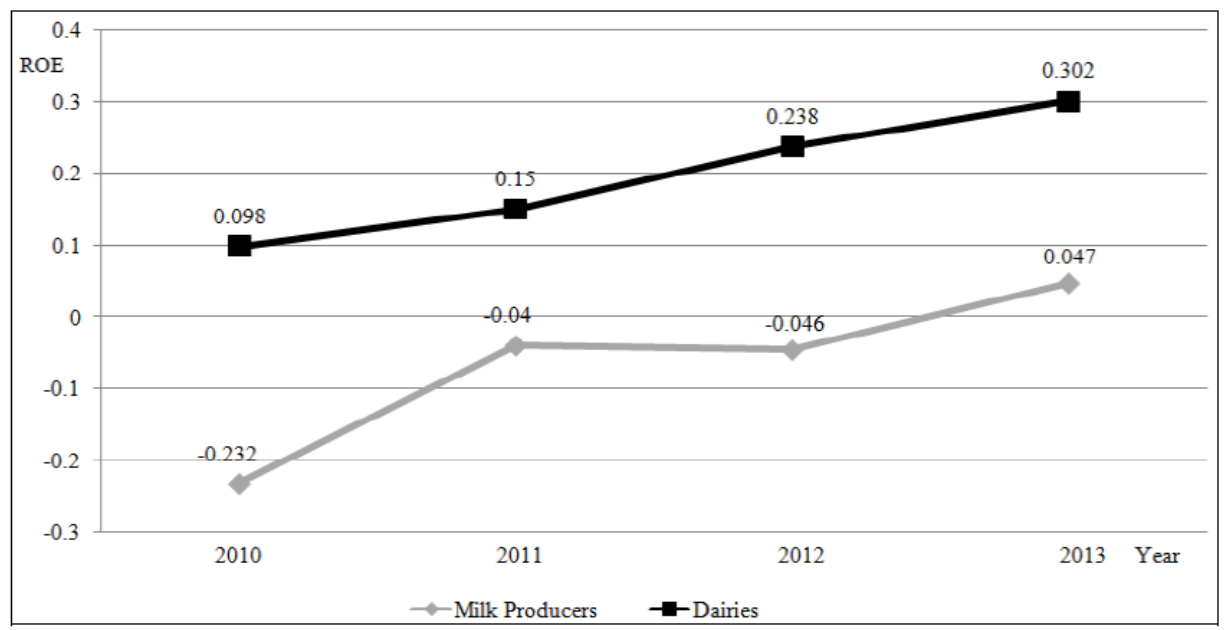

Source: Author's illustration

The research results of statistical significance of differences in the level of ROE between the two groups of participants in the chain of production of milk are presented in the following table. 
Table 6. Statistical significance of differences in the level of ROE between milk producers and dairies - Test of Between-Subject Effects for ROE

\begin{tabular}{|l|c|c|c|c|c|}
\hline Source & $\begin{array}{c}\text { Type III } \\
\text { Sum of } \\
\text { Squares }\end{array}$ & df & $\begin{array}{c}\text { Mean } \\
\text { Square }\end{array}$ & F & Sig. \\
\hline Intercept & 0.328 & 1 & 0.328 & 0.957 & 0.341 \\
\hline Group & 2.601 & 1 & 2.601 & $\underline{\mathbf{7 . 5 8 7}}$ & $\underline{\mathbf{0 . 0 1 3}}$ \\
\hline Error & 6.170 & 18 & 0.343 & & \\
\hline
\end{tabular}

Source: Author's calculations, SPSS output

Since the obtained value of $F(1,18)=7.587, p<0.05$ hypothesis $H_{2}$ is rejected and the alternative hypothesis is accepted. Thus, there are significant differences in the level of ROE between dairies and milk producers, so that dairies have significantly higher levels of ROE than the companies in the group of raw milk production.

The following table shows the results of a statistical analysis of the trend in the level of ROE for the participants in the chain of production of milk.

Table 7. Results of changes in the level of ROE - Test of Within-Subject Effects for ROE Mauchly's test

\begin{tabular}{|c|c|c|c|c|c|c|c|}
\hline $\begin{array}{c}\text { Within } \\
\text { Subjects } \\
\text { Effect }\end{array}$ & $\begin{array}{c}\text { Mauchly's } \\
\text { W }\end{array}$ & $\begin{array}{c}\text { Approx. } \\
\text { Chi- } \\
\text { Square }\end{array}$ & df & Sig. & $\begin{array}{c}\text { Greenhouse- } \\
\text { Geisser }\end{array}$ & $\begin{array}{c}\text { Huynh- } \\
\text { Feldt }\end{array}$ & $\begin{array}{c}\text { Lower- } \\
\text { bound }\end{array}$ \\
\hline ROE & 0.354 & 17.361 & 5 & $\underline{\mathbf{0 . 0 0 4}}$ & 0.601 & 0.701 & 0.333 \\
\hline
\end{tabular}

Source: Author's calculations, SPSS output

Since the value of Mauchly's test of sphericity is $2(5)=17.361, p<0.05$, the assumption of sphericity is not fulfilled. Since the value $<0.75$ it is necessary to use Greenhouse-Geisser correction.

Table 8. Results of changes in the level of ROE - Test of Within-Subject Effects for ROE Greenhouse-Geisser correction

\begin{tabular}{|l|l|c|c|c|c|c|}
\hline \multicolumn{2}{|c|}{ Source } & $\begin{array}{c}\text { Type III } \\
\text { Sum of } \\
\text { Squares }\end{array}$ & df & $\begin{array}{c}\text { Mean } \\
\text { Square }\end{array}$ & F & Sig. \\
\hline \multirow{3}{*}{$\begin{array}{l}\text { ROE } * \\
\text { Group }\end{array}$} & Sphericity Assumed & 0.324 & 3 & 0.108 & 1.135 & 0.343 \\
\cline { 2 - 7 } & Greenhouse-Geisser & 0.324 & 1.802 & 0.180 & 1.135 & $\underline{\mathbf{0 . 3 2 9}}$ \\
\cline { 2 - 7 } & Huynh-Feldt & 0.324 & 2.102 & 0.154 & 1.135 & 0.334 \\
\cline { 2 - 7 } & Lower-bound & 0.324 & 1.000 & 0.324 & 1.135 & 0.301 \\
\hline
\end{tabular}

Source: Author's calculations, SPSS output 
The value $p=0.329$ according to the Greenhouse-Geisser correction is greater than the limit value 0.05 . Therefore there are no significant differences in the change of ROE in the period 2010-2013 of participants in the chain of production of milk.

\section{Identification of Factors Affecting the Differences in the Level of Profitability (ROA and ROE) Between Dairies and Milk Producers}

Given that the application of statistical methods showed a statistically significant difference in the level of profitability measured on the basis of ROA and ROE between companies from dairy industry and raw milk production sector. Factors affecting the existence of aforementioned difference are explored in the remainder of this paper. Return on assets as an indicator of profitability is further explained through two coefficients: the profit margin (PM) and assets turnover (AT) (Walsh, 2003). Profit margin indicates to the net income per unit of sales (Kimmel et al., 2009), while asset turnover indicates how efficiently a company is using its assets to generate sales (Fairfield, Lombardi Yohn, 2001).

$R O A=P M \times A T$

$N I / T A=N I / N S \times N S / T A$

where:

NS - net sales

On the return on equity, aside of the profit margin and the asset turnover, also influences equity multiplier (see more: Mubin et al., 2014).

$$
\begin{aligned}
& R O E=R O A \times E M \\
& R O E=N I / N S \times N S / T A \times T A / S E
\end{aligned}
$$

In accordance with the second research aim set, answers to the following question should be given:

- Which one of following factors (PM, AT and/or EM) influences the existence of statistically significant differences in the levels of ROA and ROE between companies participants in the chain of production of milk.

In order to answer the aforementioned question, the following indicators are calculated for each company in the sample: profit margin, asset turnover and equity multiplier (PM, AT and EM) for the period 2010-2013. Presented in the following table is descriptive statistic PM, AT and EM for a group of companies: dairies and milk producers. 
Table 9. Descriptive statistics for PM, AT and EM for a group of companies of dairies and milk producers

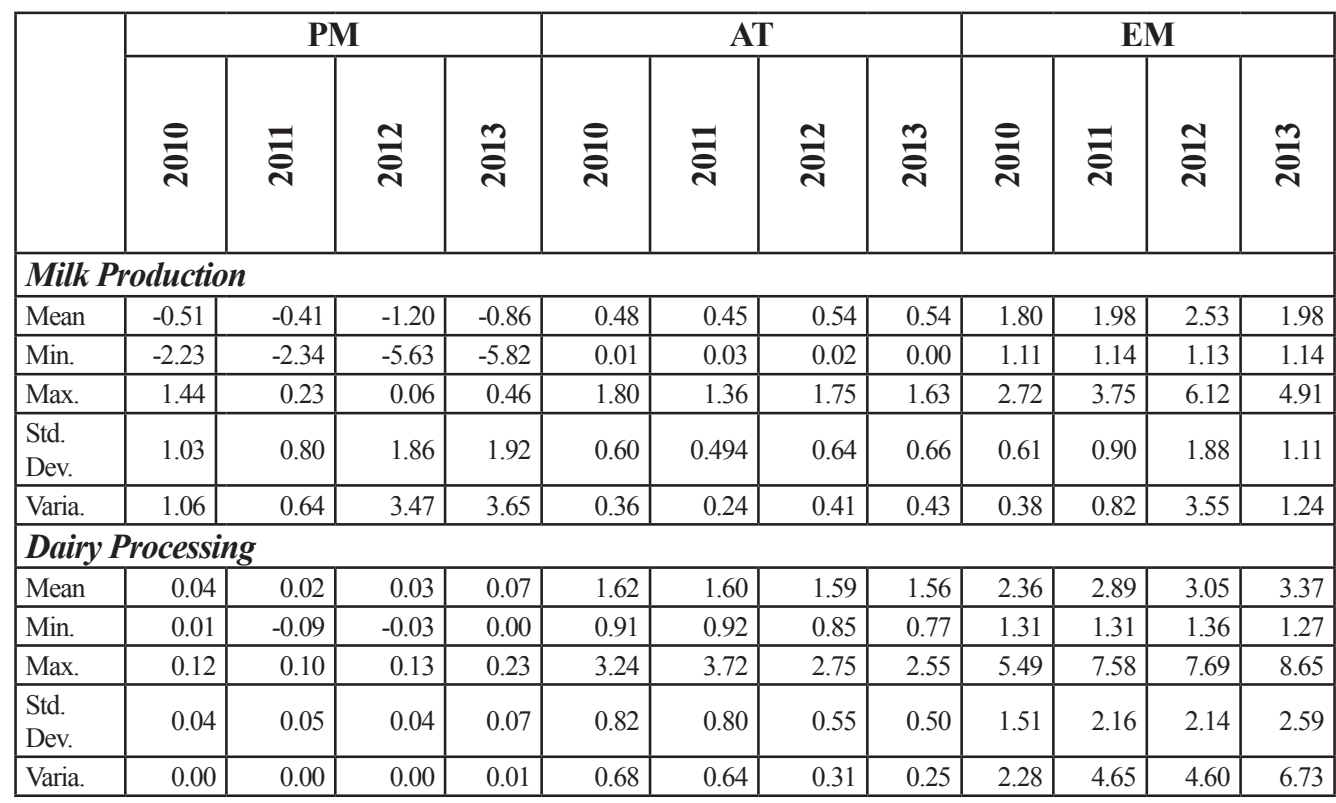

Source: Author's calculations, SPSS output

Identification of factors that significantly affect the existence of differences in the ROA and $\mathrm{ROE}$ between dairies and milk producers is based on determining the difference in the values of indicators PM, AT and EM between the two groups of companies, as these factors affect the value of the indicator of profitability. If there is a significant difference in some of these indicators, we can conclude that these factors are important to determine the differences in the level of profitability among enterprises engaged in dairy industry and raw milk production. Identifying differences in PM, AT and EM for these two groups of companies for the period 2010-2013 was conducted by using the statistical test of mixed-design repeated measures ANOVA (between-subject effects). The results of conducted statistical tests and explanations are shown in the following tables (Table 10).

Table 10. Statistical significance of differences in the level of PM, AT and EM between the dairies and milk producers - Test of Between-Subjects Effects

\begin{tabular}{|l|c|c|c|c|r|}
\hline \multicolumn{1}{|c|}{ Source } & Type III Sum of Squares & df & Mean Square & F & Sig. \\
\hline \multicolumn{1}{|c|}{$\boldsymbol{P M}$} & \multicolumn{1}{|c|}{} \\
\hline Intercept & 9.906 & 1 & 9.906 & 5.189 & 0.035 \\
\hline Group & 12.527 & 1 & 12.527 & 6.561 & $\underline{\mathbf{0 . 0 2 0}}$ \\
\hline Error & 34.366 & 18 & 1.909 & & \\
\hline
\end{tabular}




\begin{tabular}{|c|c|c|c|c|c|}
\hline Source & Type III Sum of Squares & df & Mean Square & $\mathbf{F}$ & Sig. \\
\hline \multicolumn{6}{|l|}{$A T$} \\
\hline Intercept & 87.942 & 1 & 87.942 & 57.711 & 0.000 \\
\hline Group & 23.736 & 1 & 23.736 & 15.577 & $\underline{0.001}$ \\
\hline Error & 27.429 & 18 & 1.524 & & \\
\hline \multicolumn{6}{|l|}{$E M$} \\
\hline Intercept & 498.376 & 1 & 498.376 & 51.735 & 0.000 \\
\hline Group & 14.400 & 1 & 14.400 & 1.495 & $\underline{0.237}$ \\
\hline Error & 173.397 & 18 & 9.633 & & \\
\hline
\end{tabular}

Source: Author's calculations, SPSS output

The result of the analysis - the difference in the level of profit margins at $p<0.05$ indicates that there is a statistically significant difference in the level of profit margins between dairies and milk producers. Moreover, $p<0.05$ in the analysis of differences in asset turnover ratio indicates that there is a statistically significant difference. On the other hand, the result of the analysis of differences in the level of indebtedness at $p>0.05$ indicates that there is no statistically significant difference in the level of indebtedness between dairies and milk producers.

Our research results proved that profit margin (PM) and asset turnover (AT) are identified as factors influencing the differences in the levels of profitability. Given that the difference in the level of indebtedness between dairies and milk producers is not statistically significant, it can be concluded that the debt (EM) is not a factor affecting the existence of differences in the level of profitability between these companies. Since $p=0.001$ for AT less than the $p=0.02$ for the PM, it can be concluded that among the factor influences profitability, the biggest impact has considerably higher turnover ratio assets of dairies, and then the higher profit margin.

\section{Conclusion}

Milk production is one of the essential sectors of Serbian agriculture, so there is public interest in the survival of the whole production system. This implies the necessity of a balanced business performance of all participants in the milk production chain. In order to study these relationships we made a comparative analysis of the profitability of the participants in milk production in the Republic of Serbia in the period 2010-2013. Aforementioned analysis, that was conducted on the basis of individual financial statements and on the basis of ROA and ROE as a primary indicator of the profitability, point to a significant difference in the levels of profitability between companies from the group of processors of milk - dairy, and companies from the group of breeders of cows - producers of raw milk. In other words, milk processors 
achieved significantly higher profitability compared to cow breeders.

For a more complete understanding, it is necessary to identify the causes of the gap in the level of profitability. Since ROA depends on the profit margin and asset turnover, and the ROE depends on ROA and the equity multiplier, the answer is given to the question of which factors (PM, AT and EM) influence the existence of statistically significant differences in the level of profitability between companies participants in milk production. Research results suggest that the existence of differences in the level of profitability among the participants in the milk production primarily affects capital turnover, and then the profit margin. Because there are no significant differences in the level of indebtedness between milk processors and cow breeders, it can be concluded that indebtedness is not a factor of differences in the level of ROE between these two groups of companies.

The weaker business performance of producers of raw milk, caused by a slower turnover of capital and a lower level of profitability, indicating the inferior position of agriculture in relation to the manufacturing industries. This is partly determined by the very characteristics of agricultural production - slow turnover, and partly a weaker market position, which is reflected in a lower level of profitability. The relatively unfavorable position of agriculture is a challenge for agrarian policy of Serbia, which should take into account the viability of milk production in all its segments. In this context, a key factor would be the strengthening of the market position of cow breeders, which is most efficiently done through strengthening the cooperative system, but also through other forms of support this part of livestock production. Also, attention should be paid to the conduct of antitrust policy, both in the processing of milk, as well as in distribution, or retail chain.

\section{References}

1. Berenson, M., Levine, D. and Krehbiel, T. (2012): Basic Business Statistics, Prentice Hall, Upper Saddle River.

2. Bogdanov, N., Rodic, V. (2014): Agriculture and agricultural policy in Serbia, in Volk T, Erjavec E, Mortensen K., Agriculture policy and European integration in Southeastern Europe, Food and Agriculture Organization of United Nations, Budapest.

3. Business Registers Agency (2014): Register of Companies - Financial Statements of Company Belgrade. Available at: http://www.apr.gov.rs (accessed October 9, 2014)

4. Fairfield, P., Lombardi Yohn, T. (2001): Using Asset Turnover and Profit Margin to Forecast Changes in Profitability. Review of Accounting Studies, Kluwer Academic Publisher, No. 6, pp. 371-385, Netherlands.

5. Field, A. (2009): Discovering Statistics Using SPSS, Sage Publication, London.

6. Government of the Republic of Serbia (2010): National Agricultural Programme of Serbia 2009-2011, Belgrade. Available at: http:/www.tehnologijahrane.com/standardi/ nacionalni-program-poljoprivrede-srbije-2009-2011-16\#toc-vi-sektorska-analizamlekarstvo (accessed May 5,2012)

7. Horngren, C., Harrison, W., Oliver, S. (2012): Accounting. Prentice Hall, Upper Saddle River. 
8. Kergler, B. (2012): Factors Affecting Farm Succession: the Case of Slovenia, Agricultural Economics (Zemědělská ekonomika), Czech Academy of Agricultural Sciences, vol. 58, no. 3, pp. 285-298, Praha.

9. Kimmel, P., Weygandt, J., Kieso, D., Trenholm, B. (2009): Financial Accounting, John Wiley \& Sons, Ontario.

10. Mubin, M., Iqbal, A. and Hussain, A. (2014): Determinant of Return on Assets and Return on Equity and Its Industry Wise Effects: Evidence from KSE (Karachi Stock Exchange). Research Journal of Finance and Accounting, The International Institute for Science, Technology and Education, vol. 5, no. 5, pp. 148-158, USA.

11. Muminovic, S., Pavlovic, V. (2012): Profitability of Dairy Industry in Slovenia, Croatia and Serbia, Mljekarstvo, Hrvatska mljekarska udruga, vol. 62, no. 2, pp. 96-110, Zagreb.

12. Muminovic, S., Pavlovic, V., Joksimovic, D. (2012): Profitability and Business Excellence Analysis of Dairy Industry in Serbia, Mljekarstvo, Hrvatska mljekarska udruga, vol. 62, no. 3, pp. 207-218, Zagreb.

13. Nehring, R., Gillespie, J., Sandretto, C., Hallahan, C. (2009): Small U.S. dairy farms: Can they compete?, Agricultural Economics, (Zemédělská ekonomika), Czech Academy of Agricultural Sciences, vol. 40, no. 1, pp. 817-825, Praha.

14. Popovic, R. (2008): Dairy chain analysis - the case of Serbian market, Strategic management, Ekonomski fakultet u Subotici, vol. 13, no. 1, pp. 63-67, Subotica.

15. Soboh, R. A. M. E., Lansik, A. O., Van Dijk, G. (2011): Distinguishing dairy cooperatives from investor-owned firms in Europe using financial indicators. Agribusiness. John Wiley \& Sons, Inc., no. 27, pp. 34 46. USA.

16. Statistical Office of the Republic of Serbia (2014): Electronic Databases, Belgrade, Internet http://webrzs.stat.gov.rs (accessed June 4, 2014)

17. Qian, G., Zhang, Y., Wu, J., Pan, Y. (2013): Revenue Sharing in Dairy Industry Supply Chain - A Case Study of Hohhot, Journal of Integrative Agriculture, Chines Academy of Agricultural Sciences, vol. 12, no. 12, pp. 2300-2309, Peoples R China.

18. Volk, T., Rednak, M., Erjavec, E. (2014): Cross country analysis of agriculture and agricultural policy of Southeastern Europe countries in comparison with the European Union, in Volk T, Erjavec E, Mortensen K. Agriculture policy and European integration in Southeastern Europe. Food and Agriculture Organization of United Nations, Budapest.

19. Walsh, C. (2003): Key Management Ratios, Prentice Hall, London.

20. Wilson, P. (2011): Decomposing variation in dairy profitability: the impact of output, inputs, prices, labour and management, Journal of Agricultural Science, Cambridge University Press, vol. 149, no. 4, pp. 507 - 517, UK. 


\title{
GEP U PROFITABILNOSTI U LANCU PROIZVODNJE MLEKA: ISKUSTVA U SRBIJI
}

\author{
Stanislav Zekić, ${ }^{5}$ Kristina Mijić ${ }^{6}$, Dejan Jakšić ${ }^{7}$, Ivan Milenkovic ${ }^{8}$
}

\begin{abstract}
Apstrakt
Cilj rada je da se sprovede komparacija profitabilnosti velikih prerađivača mleka $i$ velikih proizvođača mleka, odnosno farmi koje imaju više od 100 krava i organizovane su kao privredna društva. Profitabilnost je analizirana na bazi indikatora povrata na imovinu $i$ povrata na kapital. Analiza razlika u profitabilnosti ukazuje da prerađivači mleka ostvaruju statistički značajno bolju profitabilnost u odnosu na proizvođače mleka (farme). Rezultati daljeg istraživanja ukazuju da obrt imovine i profitna marža uzrokuju razlike u nivou profitabilnosti između proizvođača i prerađivača mleka.
\end{abstract}

Ključne reči: profitabilnost, proizvođači mleka, mlekare, $R O A, R O E$.

5 Vanredni profesor, dr Stanislav Zekić, Univerzitet u Novom Sadu, Ekonomski fakultet u Subotici, Segedinski put br. 9-11, 24000 Subotica, Republika Srbija, E-mail: zekics@ef.uns.ac.rs

6 Asistent, dr Kristina Mijić, Univerzitet u Novom Sadu, Ekonomski fakultet u Subotici, Segedinski put br. 9-11, 24000 Subotica, Republika Srbija, E-mail: mijick@ef.uns.ac.rs

7 Redovni profesor, dr Dejan Jakšić Univerzitet u Novom Sadu, Ekonomski fakultet u Subotici, Segedinski put br. 9-11, 24000 Subotica, Republika Srbija, E-mail: jaksicd@ef.uns.ac.rs

8 Vanredni profesor, dr Ivan Milenković, Univerzitet u Novom Sadu, Ekonomski fakultet u Subotici, Segedinski put br. 9-11, 24000 Subotica, Republika Srbija, E-mail: imilenkovic@ef.uns.ac.rs

EP 2016 (63) 2 (485-499) 